\title{
A Case Study on Thermal Efficiency Analysis of Hybrid Steam Condenser with Corrugated tubes in Thermal Power Plant
}

\author{
Mahesh K, Lasheer Shareef Mohammad, Krishna Mylapalli \\ (CYIENT Ltd, Hyderabad, India)
}

\begin{abstract}
In the present generation, the rise in demand for energy is increasing rapidly because of increase in fast growing world's industrial sector. The coal fired thermal power station is one of the effective and economical systems developed for the conversion of heat energy into mechanical work. Steam surface condensers are widely used in the power generation industry. The improvement of the performance of condensers could result in a significant increase in the efficiency and energy saving. Therefore, it is of great importance to understand the fluid flow and heat transfer in condensers in order to improve the design of condensers. This paper focuses on the effect of cooling water temperature and flow rate on the condenser performance. A theoretical study about thermal analysis and design considerations of a steam condenser are carried out as a case study. The use of a hybrid steam condenser along with corrugated tubes enables higher efficiency of the steam power plant by lowering condenser steam pressure and increasing the vacuum inside the condenser.
\end{abstract}

Keywords - Rankine cycle, Heat exchanger, Hybrid steam condenser, Jet nozzle, LMTD, Corrugated tubes

\section{INTRODUCTION}

A power plant is assembly of systems and subsystems to generate electricity. The power plant should be useful economically and environmental friendly to the society. The ultimate goal is to develop, design, and manufacturer the non-conventional power generating systems in coming decades preferably after 2050 . The main equipment for the generation of electrical power is generator. When coupling it to a major mover runs the generator, the electricity is generated [1]. Steam power plant works on Rankine Cycle. The Rankine cycle is an ideal thermodynamic cycle of a heat engine that converts heat into mechanical work. The heat is supplied externally to a closed-loop system, which usually uses water as the working fluid as shown in Fig 1.

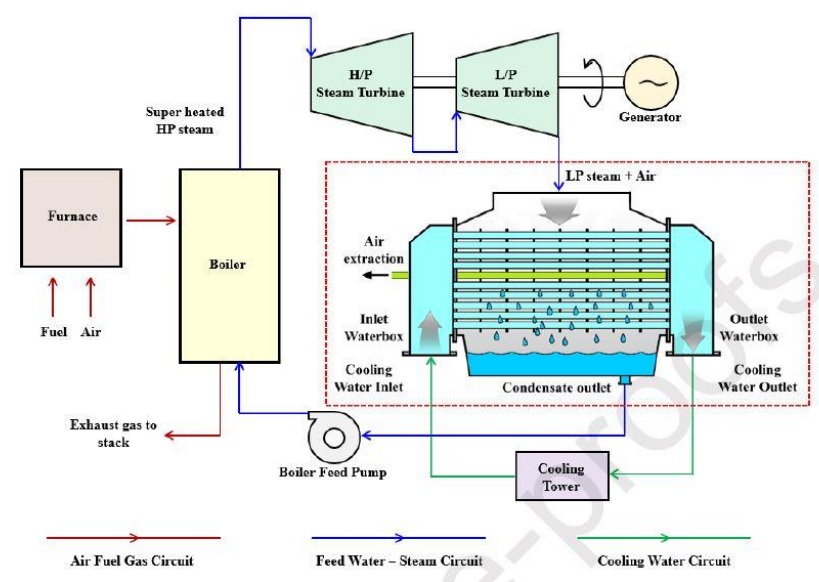

Figure 1: Power plant system with steam surface condenser

The basic processes in Rankine cycle are [2]:

iv. Isobaric Heat addition

Initially, coal is burnt in a boiler. As a result, large amount of heat energy is liberated. This is given to the water at a constant pressure. So the water will be converted into the steam. This process is shown in Fig 2 (4-1).

ii. Isentropic Expansion

The steam that is coming from the boiler is superheated to avoid moisture. This high velocity jet impinges on the turbine blades and rotates the turbine. Since the generator is coupled to the turbine, it produces electricity. This process is shown in Fig 2 (1-2).

\section{iii. Isobaric Heat Rejection}

The exhaust steam from the turbine is sucked by the condenser. In condenser, the pressure below the atmosphere is maintained. So the enthalpy drop in the turbine is increased. As a result, work output is increased. Here steam condenses and latent heat of evaporation released by the steam is absorbed by cooling water. Steam is converted into the water. This process is shown in Fig 2 (2-3).

iv. Isentropic Compression

The pump then returns the water to the boiler isentropically to reduce the work input. This process is shown in Fig 2 (3-4). 


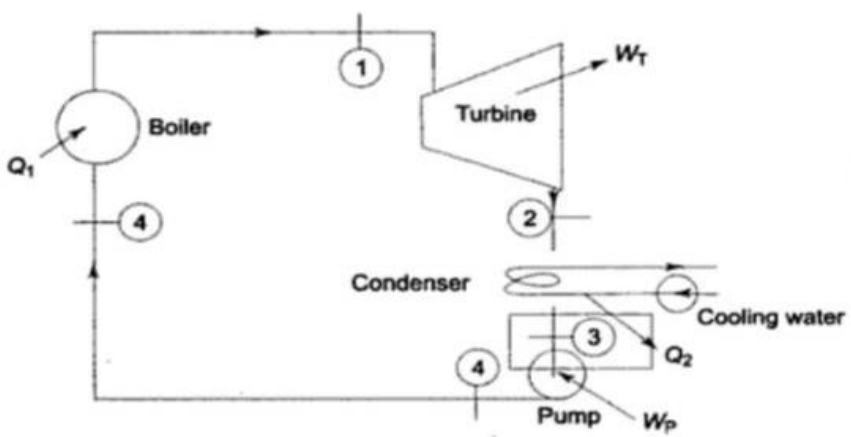

Figure 2: Schematic diagram of steam power plant

Efficiency of the Rankine Cycle:

Considering $1 \mathrm{~kg}$ of fluid, Applying steady flow energy equation (S.F.E.E.) to boiler, turbine, condenser and pump,

(i) For boiler

We get,

$$
\begin{aligned}
& \mathrm{h}_{\mathrm{f} 4}+\mathrm{Q}_{1}=\mathrm{h}_{1} \\
& \therefore \mathrm{Q}_{1}=\mathrm{h}_{1}-\mathrm{h}_{\mathrm{f} 4}
\end{aligned}
$$

(ii) For turbine

We get, $\quad \mathrm{h}_{1}=\mathrm{W}_{\mathrm{T}}+\mathrm{h}_{2}$

Where $\mathrm{W}_{\mathrm{T}}=$ turbine work

$$
\therefore \mathrm{W}_{\mathrm{T}}=\mathrm{h}_{1}-\mathrm{h}_{2}
$$

(iii) For condenser

$$
\begin{array}{ll}
\text { We get, } & \mathrm{h}_{2}=\mathrm{Q}_{2}+\mathrm{h}_{\mathrm{f} 3} \\
& \therefore \mathrm{Q}_{2}=\mathrm{h}_{2}-\mathrm{h}_{\mathrm{f} 3}
\end{array}
$$

(iv) For feed pump

$$
\begin{array}{ll}
\text { We get, } & \mathrm{h}_{\mathrm{f} 3}+\mathrm{W}_{\mathrm{P}}=\mathrm{h}_{\mathrm{f} 4} \\
\text { Where, } & \mathrm{W}_{\mathrm{P}}=\text { Pump work } \\
& \therefore \mathrm{W}_{\mathrm{P}}=\mathrm{h}_{\mathrm{f} 4}-\mathrm{h}_{\mathrm{f} 3}
\end{array}
$$

The feed pump handles liquid water which is incompressible which means, with the increase in pressure its density or specific volume undergoes a little change. Using general property relation for reversible adiabatic compression, we get,

$$
\begin{aligned}
& \text { Tds }=\mathrm{dh}-\mathrm{vdp} \\
& \mathrm{d} \mathrm{s}=0 \\
& \therefore \mathrm{dh}=\mathrm{vdp} \\
& \text { Or } \quad \Delta \mathrm{h}=\mathrm{v} \Delta \mathrm{p} \text { (since change in specific volume }
\end{aligned}
$$
is negligible)

$$
\text { Or } \mathrm{h}_{\mathrm{f} 4}-\mathrm{h}_{\mathrm{f} 3}=\mathrm{v}_{3}\left(\mathrm{p}_{1}-\mathrm{p}_{2}\right)
$$

Where $\mathrm{p}$ is in bar and $\mathrm{v}$ is in $\mathrm{m}^{3} / \mathrm{kg}$,

We have

$$
\mathrm{h}_{\mathrm{f} 4}-\mathrm{h}_{\mathrm{f3}}=\mathrm{v}_{3}\left(\mathrm{p}_{1}-\mathrm{p}_{2}\right) \times 105 \mathrm{~J} / \mathrm{kg}
$$

The feed pump term $\left(\mathrm{h}_{\mathrm{f} 4}-\mathrm{h}_{\mathrm{f} 3}\right)$ being a small quantity in comparison with turbine work,

$\mathrm{W}_{\mathrm{T}}$, is usually neglected, especially when the boiler pressures are low.

$$
\text { Then, } \eta_{\text {Rankine }}=\frac{h_{1}-h_{4}}{h_{1}-h_{f 4}}
$$

Steam is especially required for power generation and process heating purposes. The capacity of the boilers used for power generation is significantly large compared with other boilers. Due to the need of high efficiency, the steam for power generation is produced at high pressures and in huge quantities [3].

The surface condenser is one of the most important supplementary components that affect the efficiency and performance of the power plant. A steam surface condenser usually refers to a water-cooled shelland-tube heat exchanger that is installed on the exhaust steam from a steam turbine in a thermal power station [4]. A surface condenser is a device in which the exhaust steam from the steam turbine is condensed by the cooling water inside the tube bundle as shown in Fig 3.

The surface condenser is part of two cycles in a typical thermal power station: the feed water / steam circuit and the cooling water circuit. Steam enters the condenser shell through the steam inlet connection, which is usually located at the top of the condenser. When the steam touches the relatively cold tubes, it condenses. This change in state results in a great reduction in the specific volume, which creates a vacuum in the condenser [5]. A vacuum venting system is connected to the air extraction and used to support the condenser vacuum by continually removing any air that enters the system. The tubes are kept cold by the circulation of water in a cooling water circuit, which removes the heat from the condensing steam. The condensate is continually removed from the hot well by a condensate pump and is discharged into the condensate system. Therefore, the performance of the steam surface condenser directly affects the operation of any power plant and its optimization.

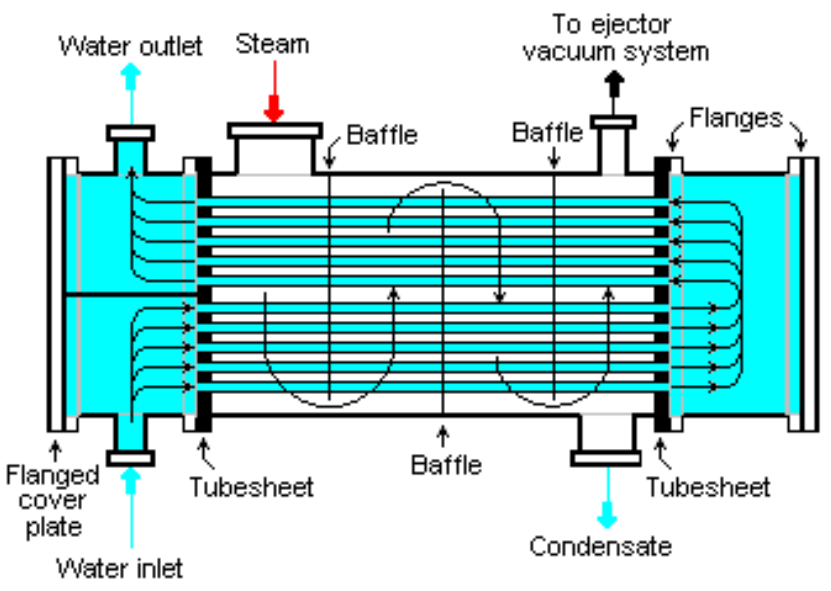

Figure 3: Power Plant Surface Condenser

A. Advantages of Surface condenser:

- The condensate is often used as boiler feed water.

- Cooling water of even poor quality is often used because the cooling water doesn't come in direct contact with steam.

- High vacuum (about $73.5 \mathrm{~cm}$ of $\mathrm{Hg}$ ) are often obtained within the surface condenser. This increases the thermal efficiency of the plant.

B. Disadvantages of surface condenser:

- The capital cost is more. 
- The upkeep cost and running cost of this condenser is high.

- It is bulky and requires more space.

\section{Requirements of a modern surface condenser}

The requirements of ideal surface condenser used for power plants are as follows [6]:

- The steam entering the condenser should be evenly distributed over the entire cooling surface of the condenser vessel with minimum pressure loss.

- The quantity of cooling water being circulated within the condenser should be so regulated that the temperature of cooling water leaving the condenser is like saturation temperature of steam corresponding to steam pressure in the condenser. This will help in preventing under cooling of condensate.

- The deposition of dirt on the outer surface of tubes should be prevented.

- There should be no air leakage into the condenser because presence of air destroys the vacuum within the condenser and thus reduces the work obtained per $\mathrm{kg}$ of steam. If there is leakage of air into the condenser air extraction pump won't remove air as rapidly as possible.

\section{Jet Condenser}

In Jet condensers the exhaust steam and cooling water will come in direct contact with each other as shown in Fig 4. The temperature of cooling water and therefore the condensate is same when leaving the condensers [7].

Elements of the jet condenser are as follows:

- Nozzles or distributors for the condensing water.

- Steam inlet.

- Mixing chambers: They may be

(a) Parallel flow type

(b) Counter flow type depending on whether the steam and water move in the same direction before condensation or whether the flows are opposite.

- Hot well.

In jet condensers the condensing water is named as injection water.

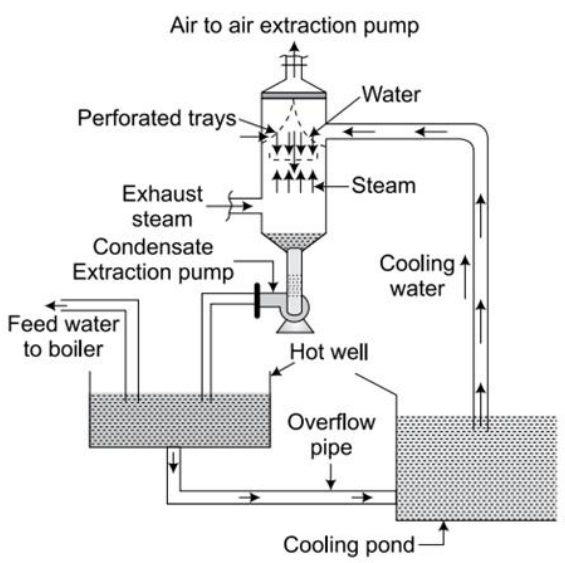

Figure 4: Jet Condenser in Thermal Power Plant

\section{REASONS FOR THE POOR EFFICIENCY OF CONDENSER}

The inefficiency of condenser is mainly due to the rise in pressure of the condenser. The gases will cover the outer surface of the tubes. This will severely reduce the heat transfer rates of the steam to the circulating water therefore pressure in the condenser will increase. This rise in pressure will reduce the turbine output and efficiency. The corrosiveness of the condensate in the condenser increases as the oxygen content raises. Thus, these gases must be removed in order to enhance the life of the condenser [8].

Sources:

- Presence of Air

- Non-Condensable Gases

- Leakages

- Turbine seals.

- Poor condenser design leads to tube failures.

- Tube manufacturing defects.

- Dissociation of Water into Hydrogen and Oxygen.

\section{NEED TO IMPROVE THE EFFICIENCY OF THE CONDENSER}

Thermal efficiency of a Rankine cycle is represented as $\left(T_{1}-T_{2}\right) / T_{1}$. Where, $T_{1}$ is source temperature and $T_{2}$ is the sink temperature. This expression of efficiency shows that the efficiency increases with an increase in temperature $T_{1}$ and decrease in temperature $T_{2}$. The maximum temperature $T_{1}$ of the steam supplied is restricted by material considerations. The temperature $T_{2}$ (temperature at which heat is rejected) are often reduced to the atmospheric temperature if the exhaust of the steam takes place below air pressure. If the exhaust is at air pressure, the heat rejection is at $100^{\circ} \mathrm{C}$. Low exhaust pressure is necessary to obtain low exhaust temperature. But the steam can't be exhausted to the atmosphere if it's expanded in the engine or turbine to a pressure less than the air pressure. Under this condition, the steam is exhausted into a vessel referred to as condenser where the pressure is maintained below the atmosphere by continuously condensing the steam by means of circulating cold water at atmospheric temperature [9].

Basically, a condenser may be a device where steam condenses and heat of transformation of evaporation released by the steam is absorbed by cooling water. First, it maintains a really low back pressure on the exhaust side of the turbine. As a result the steam expands to a greater extent and consequently leads to an increase in work output. Then, the exhaust steam condensate is free from impurities. Thermal efficiency of a condensing unit is above that of a non-condensing unit for equivalent available steam properties.

Condenser increases vacuum. It changes dead steam into live feed water. It reduces the cost of supply of cleaning and treating of working fluid. It improves the efficiency of the cycle by allowing the plant to operate on largest possible temperature difference between source and sink and provides good quality feed water to the boiler. It decreases work input to the pump. It offers re usability of 
steam in the cycle again. It provides de-aeration to the condensate.

The performance of condensers has been studied by several authors and various methods were developed. Chisholm et. al. (1965) developed a numerical method of evaluating heat and mass transfer coefficient and local heat fluxes in surface condensers. An iterative process was used to solve heat and mass transfer equations for each row of tube in condensers [10].

H. E. I. (1978) investigated the Standards for Steam Surface Condensers. Bell (1983) showed the trends in design and application of condensers in the process industries. Davidson (1987) studied the thermal design of condensers for large low pressure turbines. Lang (1987) studied about the steam condenser developments essentially for low pressure steam turbines. Rhodes and Marsland (1993) improved the performance of the Condenser using CFD. Howell (2005) analyzed the components failure in power plant due to corrosion and to prevent leakage of condenser tubes. Saxon (2005) concluded that the condenser tube fouling and failure occur due to streamside and water side of tubes that can be caused by chemical or mechanical factors and reduced by de-mineralizing and de-aerating [11-12].

Kapooria (2008) theoretically analyzed the conceptual technological design aspect of a super vacuum hybrid surface steam condenser. Kumar (2008) has undertaken theoretical investigation about thermal analysis and design considerations of a steam condenser. Kasana (2008) concluded that vacuum can be increased if we use both types of condensers i.e. Jet and Surface Condensers. Rooyen and Kroger (2008) showed the performance trends of an air cooled steam condenser under windy conditions. Wang et al. showed the CFD simulation on a thermal power plant with air-cooled heat exchanger system. Hajidavalloo and Eghtedari (2010) investigated the Performance improvement of air-cooled refrigeration system by using evaporatively cooled air condenser. Boca (2011) developed a heat exchanger consisting of tube bundle and water chambers. Cooling medium (water) cools down and regenerates by means of heat exchanging surface the steam out going of the turbine of power station. The vacuum efficiency of the condenser is decreased due to increase in pressure of the condenser. It is mainly due to the presence of air, oxygen, non-condensable gases and leakages. In this project, the design of the surface condenser has been modified by adding jet condenser, nozzle and corrugated tubes to increase vacuum efficiency and heat transfer rate [13-15].

\section{ANALYTICAL MODELING}

The steam condenses in the condenser on a cooling coil. The condensate is stored at the bottom of the condenser known as hot well. To develop an intermediate complexity model, the following assumptions are made [7]:

- The maximum film thickness is small when compared to the tube diameter.

- Steady state one dimensional flow.

- The condensate flow is laminar.

- The cooling water flow is turbulent.
- The logarithmic mean temperature difference is an exact representation of the average temperature difference between the fluid and the surface.

- Heat transfer over/from the condensate at the bottom of the condenser is negligible.

The counter flow heat exchange steam condenser is the most effective when heat transfer rate per unit area is considered. It is due to the typical temperature difference $(\Delta \mathrm{T})$ between the 2 fluids over the length that the heat exchange processing is maximized. Therefore, the log mean temperature difference for a counter flow heat exchange steam condenser is larger than the log mean temperature for an identical parallel or cross flow heat exchange steam condensers. The log mean temperature difference for a heat exchange unit is calculated using the subsequent equation:

$$
\Delta \mathrm{T}_{\mathrm{lm}}=\left(\Delta \mathrm{T}_{2}-\Delta \mathrm{T}_{1}\right) / \ln \left(\Delta \mathrm{T}_{2} / \Delta \mathrm{T}_{1}\right)
$$

Where, $\mathrm{T}_{1}=$ Hot fluid temperature and $\mathrm{T}_{2}=$ Cold fluid temperature. Heat transfer in a heat exchange condenser is assumed to occur by conduction and convection. The rate of heat transfer, ' $Q$ ', in a heat exchange steam condenser is calculated by using the following equation:

$$
\mathrm{Q}=\mathrm{U}_{\mathrm{o}} \mathrm{A}_{\mathrm{o}} \Delta \mathrm{T}_{1 \mathrm{~m}}
$$

In simulation, the heat exchanger is mathematically modeled to establish relations amongst condensing parameters. Prediction of outlet and inlet temperatures for different flow rates is simulated by using various equations for the heat transfer rate discussed below [16]:

$\left.\left(\mathrm{T}_{\mathrm{h}, \mathrm{o}}-\mathrm{T}_{\mathrm{c}, \mathrm{i}}\right)\right]$

$$
\begin{aligned}
& \mathrm{Q}=\mathrm{C}_{\mathrm{h}}\left(\mathrm{T}_{\mathrm{h}, \mathrm{i}}-\mathrm{T}_{\mathrm{h}, \mathrm{o}}\right) \\
& \mathrm{Q}=\mathrm{C}_{\mathrm{c}}\left(\mathrm{T}_{\mathrm{c}, \mathrm{o}}-\mathrm{T}_{\mathrm{c}, \mathrm{i}}\right) \\
& \mathrm{Q}=\mathrm{UA}\left(\mathrm{T}_{\mathrm{h}, \mathrm{i}}-\mathrm{T}_{\mathrm{c}, \mathrm{o}}\right)-\left(\mathrm{T}_{\mathrm{h}, \mathrm{o}}-\mathrm{T}_{\mathrm{c}, \mathrm{i}}\right) / \ln \left[\left(\mathrm{T}_{\mathrm{h}, \mathrm{i}}-\mathrm{T}_{\mathrm{c}, \mathrm{o}}\right) /\right.
\end{aligned}
$$

These three equations contain three unknowns viz,

$\mathrm{Q}, \mathrm{T}_{\mathrm{h}, \mathrm{o}}$ and $\mathrm{T}_{\mathrm{c}, \mathrm{o}}$. The number of unknowns can be reduced to 2 by eliminating $\mathrm{Q}$ to give:

$$
\mathrm{C}_{\mathrm{h}}\left(\mathrm{T}_{\mathrm{h}, \mathrm{i}}-\mathrm{T}_{\mathrm{h}, \mathrm{o}}\right)=\mathrm{C}_{\mathrm{c}}\left(\mathrm{T}_{\mathrm{c}, \mathrm{o}}-\mathrm{T}_{\mathrm{c}, \mathrm{i}}\right)
$$

$\mathrm{C}_{\mathrm{h}}\left(\mathrm{T}_{\mathrm{h}, \mathrm{i}}-\mathrm{T}_{\mathrm{h}, \mathrm{o}}\right)=\mathrm{UA}\left(\mathrm{T}_{\mathrm{h}, \mathrm{i}}-\mathrm{T}_{\mathrm{c}, \mathrm{o}}\right)-\left(\mathrm{T}_{\mathrm{h}, \mathrm{o}}-\mathrm{T}_{\mathrm{c}, \mathrm{i}}\right) / \ln$ $\left[\left(\mathrm{T}_{\mathrm{h}, \mathrm{i}}-\mathrm{T}_{\mathrm{c}, \mathrm{o}}\right) /\left(\mathrm{T}_{\mathrm{h}, \mathrm{o}}-\mathrm{T}_{\mathrm{c}, \mathrm{i}}\right)\right]$

Solving for $\mathrm{T}_{\mathrm{c}, \mathrm{o}}$ in Eq. (11) and substituting into Eq. (12) we get,

$\ln \left\{\mathrm{T}_{\mathrm{h}, \mathrm{i}}-\left[\mathrm{T}_{\mathrm{c}, \mathrm{i}}+\left(\mathrm{C}_{\mathrm{h}} / \mathrm{C}_{\mathrm{c}}\right)\left(\mathrm{T}_{\mathrm{h}, \mathrm{i}}-\mathrm{T}_{\mathrm{h}, \mathrm{o}}\right)\right] /\left(\mathrm{T}_{\mathrm{h}, \mathrm{o}}-\right.\right.$ $\left.\left.\mathrm{T}_{\mathrm{c}, \mathrm{i}}\right)\right\}=\mathrm{UA}\left(1 / \mathrm{C}_{\mathrm{h}}-1 / \mathrm{C}_{\mathrm{c}}\right)$

Let $\operatorname{UA}\left(1 / \mathrm{C}_{\mathrm{h}}-1 / \mathrm{C}_{\mathrm{c}}\right)=\mathrm{x}$ Then,

$\mathrm{e}^{\mathrm{x}}$

$$
\left[\mathrm{T}_{\mathrm{h}, \mathrm{i}}-\mathrm{T}_{\mathrm{c}, \mathrm{i}}-\left(\mathrm{C}_{\mathrm{h}} / \mathrm{C}_{\mathrm{c}}\right)\left(\mathrm{T}_{\mathrm{h}, \mathrm{i}}-\mathrm{T}_{\mathrm{h}, \mathrm{o}}\right)\right] /\left[\left(\mathrm{T}_{\mathrm{h}, \mathrm{o}}-\mathrm{T}_{\mathrm{c}, \mathrm{i}}\right)\right]=
$$

Solving for $\mathrm{T}_{\mathrm{h}, \mathrm{o}}$ enables,

$$
\begin{aligned}
& \mathrm{T}_{\mathrm{h}, \mathrm{o}}=\mathrm{T}_{\mathrm{h}, \mathrm{i}}\left(\mathrm{C}_{\mathrm{h}} / \mathrm{C}_{\mathrm{c}}-1\right)+\mathrm{T}_{\mathrm{c}, \mathrm{i}}\left(1-\mathrm{e}^{\mathrm{x}}\right) /\left(\mathrm{C}_{\mathrm{h}} / \mathrm{C}_{\mathrm{c}}-\mathrm{e}^{\mathrm{x}}\right) \\
& \text { Or, } \\
& \mathrm{T}_{\mathrm{h}, \mathrm{o}}=\left[\mathrm{T}_{\mathrm{h}, \mathrm{i}}-\left(\mathrm{T}_{\mathrm{h}, \mathrm{i}}-\mathrm{T}_{\mathrm{c}, \mathrm{i}}\right)\right]\left[\left(1-\mathrm{e}^{\mathrm{x}}\right) /\left(\mathrm{C}_{\mathrm{h}} / \mathrm{C}_{\mathrm{c}}-\mathrm{e}^{\mathrm{x}}\right)\right]
\end{aligned}
$$

Equation 13 gives the outlet temperature of the recent fluid when $T_{h, i}$ and $T_{c, i}$ are known. The outlet temperature of the cold is often computed by using Equation 13. In the above simulation, the subscripts $\mathrm{c}$ and $\mathrm{h}$ designates cold and hot fluids, whereas the subscripts $i$ and o ask the fluid inlet and outlet conditions, respectively.

Steam surface condensers can be broadly categorized by the design of the orientation of the steam 
turbine exhaust into the condenser. The air ejector illustrated in Fig 5 is essentially a jet pump which has two sorts of fluids. One fluid flows through the nozzle at a high and therefore the other fluid being pumped, flows round the nozzle into the throat of the diffuser. These two fluids collide within the diffuser where molecules of high velocity fluid strike with other fluid molecules. Thus, at the diffuser end, low velocity molecules become a part of a high velocity molecules stream as results of entrainment, which successively, creates a pressure area around the mouth of the nozzle. This low area will enable suction or pumping of more fluid from round the nozzle into the throat of the diffuser. As the fluid leaves the diffuser throat area, the diverging area converts the speed back to the pressure. It has been observed that use of steam as a high fluid from the source at a pressure between 200 psi and 300 psi enables a vacuum of about 26 inches of $\mathrm{Hg}$ by employing a single stage air ejector.

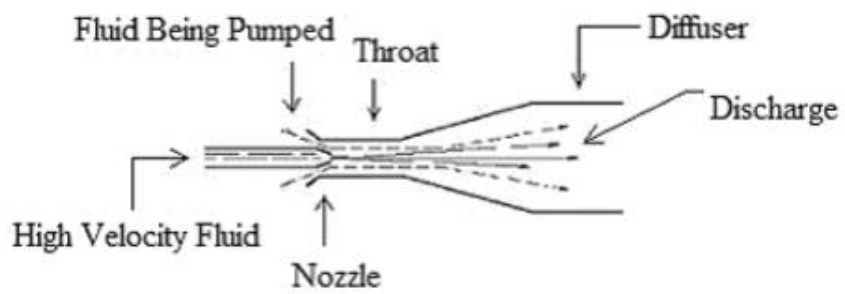

Figure 5: Jet pump principle

Normally, air ejectors consist of two suction stages. The first stage suction is found on top of the condenser, while the second stage suction comes from the diffuser. The exhaust steam from the second stage needs to be condensed. This is normally accomplished by an air ejector condenser that's cooled by condensate. The air ejector condenser also preheats the condensate recurring to the boiler. Two-stage air ejectors are accomplished of drawing vacuums to 29 inches $\mathrm{Hg}$. A vacuum pump may be a motor-driven air compressor. Its suction is attached to the condenser, and it discharges to the atmosphere [17].

\section{DESIGN OF SUPER VACCUM HYBRID STEAM CONDENSER}

A hybrid super vacuum steam condenser may be a device with a mixture of jet condensing and surface condensing systems. The exhaust steam at the inlet of the condenser is allowed to split into two streams. One stream of exhaust steam at high velocity and low, is diverted into a chamber where mixing occurs with outlet cooling water as shown in Fig 6. The other stream goes onto the surface of the water cooling tubes of the condenser. The outlet cooling water should be clean or a filter is important at the jet exit [17].

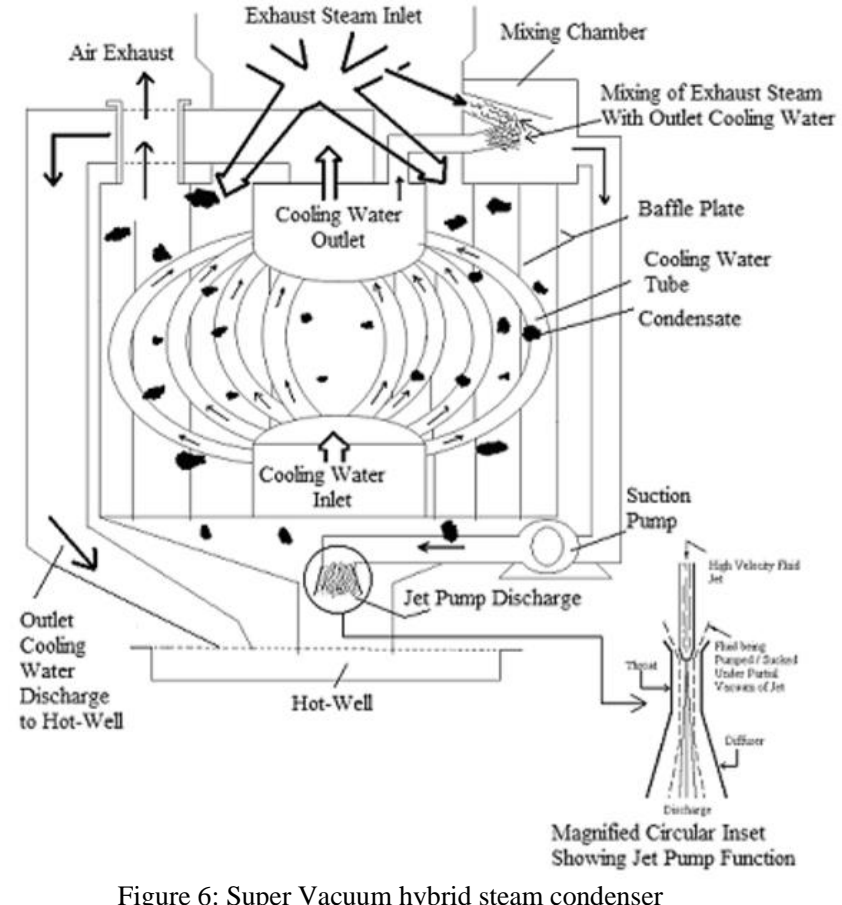

The fluid from the blending chamber is sucked by a pump and is discharged through a nozzle as a high velocity jet. This nozzle is united with the outlet of the condenser shell opening from where condensate is discharged to the hot-well. The hot well discharge opening of the condenser shell is intended because the part of a diffuser throat where the nozzle releases high velocity cooling water through a mixed condensate jet. This nozzle and diffuser throat position is represented in Fig 6. This high velocity jet creates a pressure area round the mouth of the nozzle which enables pulling of the tube surface condensate. Both the condensate i.e. jet condensate and tubes surface condensate encounter at the diffuser throat expansion and gets mixed with hot-well fluid.

In corrugated tubes, both the length and average diameter of the tube can be changed. This is as shown in Fig 7 Here it's possible to urge a better area for a given length and a mean diameter of a tube. In this design, the heat transfer rate is bigger due to the rise within the area. It is documented that for a given length and average diameter, the heat transfer rate is bigger within the case of a corrugated tubes condenser than the flat tubes condenser. Theoretically, this condenser design with a hybrid super vacuumed mechanism is most effective than the other type for the subsequent reasons:

- The heat transfer rate is greater than any other type due to:

- Higher surface area of the corrugated tube.

- Counter flow pattern of cooling water;

- Higher vacuum efficiency

\section{A. Calculation of the efficiency of the existing condenser in TPP at Vizag Steel Plant}

Steam inlet temperature $\left(\mathrm{T}_{\mathrm{h}, \text { in }}\right)=51.77^{\circ} \mathrm{C}$

Steam outlet temperature $\left(\mathrm{T}_{\mathrm{h}, \text { out }}\right)=51.77^{\circ} \mathrm{C}$

Cooling water inlet temperature $\left(\mathrm{T}_{\mathrm{c}, \text { in }}\right)=38.16^{\circ} \mathrm{C}$ 
Cooling water outlet temperature $\left(\mathrm{T}_{\mathrm{c}, \text { out }}\right)=44.34^{\circ} \mathrm{C}$

Mass flow rate of steam $\left(\mathrm{m}_{\text {steam }}\right)=288.5 \mathrm{~T} / \mathrm{hr}=80.14 \mathrm{~kg} / \mathrm{s}$

Total no. of tubes in the condenser $(n)=9000$

Diameter of the tubes $(\mathrm{d})=20 \mathrm{~mm}$

Length of the tube $(1)=17 \mathrm{~m}$

Condenser Vacuum $=-0.761 \mathrm{~kg} / \mathrm{cm} 2=0.26646 \mathrm{bar}$

Saturation temperature $=66.4^{\circ} \mathrm{C}$

Heat Transfer rate $=\mathrm{m}_{\text {steam }} \times \mathrm{h}_{\mathrm{fg}}$ (By Assuming quality of the steam =1)

Where $\mathrm{m}_{\mathrm{s}}=$ Mass Flow rate of steam in $\mathrm{Kg} / \mathrm{s}$

$\mathrm{h}_{\mathrm{fg}}=$ Latent heat of Evaporation

$$
\begin{aligned}
& =80.14 \times 2.342 \times 1000 \times 1000 \\
& =188 \mathrm{MW}
\end{aligned}
$$

Surface area $($ As $)=\mathrm{n} \times \pi \times \mathrm{d} \times 1$

$$
\begin{aligned}
& =9000 \times \pi \times 0.02 \times 17 \\
& =9613.27 \mathrm{~m}^{2}
\end{aligned}
$$

Logarithmic mean temperature difference $($ LMTD $)=$ $\frac{\Delta \mathrm{T} 1-\Delta \mathrm{T} 2}{\ln \frac{\Delta \mathrm{T} 1}{\Delta \mathrm{T} 2}}$

$$
\begin{gathered}
\text { Where } \begin{aligned}
\Delta \mathrm{T} 1 & =\mathrm{T}_{\mathrm{h}, \text { in }}-\mathrm{T}_{\mathrm{c}, \text { out }} \\
\Delta \mathrm{T} 2 & =\mathrm{T}_{\mathrm{h}, \text { out }}-\mathrm{T}_{\mathrm{c}, \text { in }} \\
(\mathrm{LMTD}) & =\frac{(51.77-44.34)-(51.77-38.16)}{\ln \frac{7.43}{13.61}} \\
= & 10.21^{\circ} \mathrm{C}
\end{aligned}
\end{gathered}
$$

From the equation $\mathrm{Q}=\mathrm{U} \times \mathrm{A}_{\mathrm{s}} \times \mathrm{LMTD}$

$$
188=\mathrm{U} \times 9613.27 \times 10.21
$$

Overall heat transfer coefficient $(\mathrm{U})=1915.4 \mathrm{~W} / \mathrm{m} 2{ }^{\circ} \mathrm{C}$

Efficiency of the condenser $\left(\eta_{\text {condenser }}\right)=\frac{T c, \text { out }-T c, \text { in }}{T \text { sat }-T c, \text { in }}$

Where $\mathrm{T}_{\mathrm{sat}}=$ Saturation temperature corresponding to condenser pressure

$$
=\frac{44.34-38.16}{66.4-38.16}
$$

$\eta_{\text {condenser }}=22 \%$

\section{B. Modifications to the existing surface condenser design}

- Addition of Jet condenser:

It reduces the volume of steam handled by the surface condenser and to reduce the impact of steam on the condenser tubes.

- Addition of Nozzle:

It creates the partial vacuum near the hot well.

- Change in shape of the cooling water tubes:

These are curved rather than straight and increase the heat transfer surface area.

\section{Design of Super Vacuum Hybrid Steam Condenser}

Finding the quality of the steam in TPP:

$\begin{array}{ll}\text { Main steam pressure } & =89.4 \mathrm{~kg} / \mathrm{cm}^{2} \\ & =89.4 \times 9.81 \times 10^{4} \\ & =87.7 \mathrm{bar} \\ \text { Main steam temperature } & =540^{\circ} \mathrm{C} \\ \text { Condenser vacuum } & =-0.761 \mathrm{~kg} / \mathrm{cm}^{2} \\ & =-0.761 \times 9.81 \times 10^{4} \\ & =-0.74654 \mathrm{bar} \\ \text { Condenser pressure } & =1.013-0.74654 \\ & =0.26671 \mathrm{bar}\end{array}$

From the steam tables,

At $540^{\circ} \mathrm{C}, 87.7$ bar:

Entropy
Entropy of steam $=0.91 \mathrm{~kJ} / \mathrm{kg} \mathrm{K}$

$\begin{array}{ll}\mathrm{S}_{\mathrm{fg}} & =6.9 \mathrm{~kJ} / \mathrm{kg} \mathrm{K} \\ \mathrm{h}_{\mathrm{f}} & =278.5 \mathrm{~kJ} / \mathrm{kg} \\ \mathrm{h}_{\mathrm{fg}} & =2343.5 \mathrm{~kJ} / \mathrm{kg}\end{array}$

$6.7838=0.91+\mathrm{x}(6.9)$

$\therefore$ Quality of steam $=0.8512$

The exhaust steam from the turbine is taken as input to the hybrid condenser.

\section{D. $75 \%$ of the steam is given to the condenser and tubes are corrugated}

Here, $3 / 4$ part of the steam that is coming from the turbine is taken as input and remaining is given to the jet condenser to reduce the volume of the steam handled by the surface condenser.

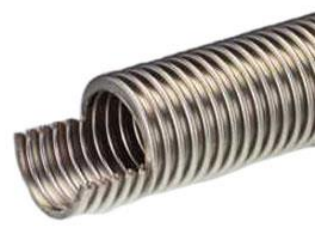

Figure 7: Corrugated tube

- Inputs for the steam condenser:

Turbine exhaust steam temperature $\left(\mathrm{T}_{\mathrm{h}, \mathrm{in}}\right)=51.77^{\circ} \mathrm{C}$

Quality of steam $=0.8512$

Cooling water inlet temperature $\left(\mathrm{T}_{\mathrm{c}, \text { in }}\right)=38.16^{\circ} \mathrm{C}$

Mass flow rate of steam $\left(\mathrm{m}_{\text {steam }}\right)=80.14 \mathrm{~kg} / \mathrm{s}$

- Output from the steam condenser:

Condenser exit condensate temperature $\left(\mathrm{T}_{\mathrm{h}, \text { out }}\right)=51.77^{\circ} \mathrm{C}$

$\therefore$ From Heat balance equation

Heat lost by steam $=$ Heat gained by cooling water

$3 / 4 \times m_{\text {steam }} \times\left(\mathrm{x} \mathrm{h}_{\mathrm{fg}}\right)=\mathrm{m}_{\mathrm{w}} \times \mathrm{C}_{\mathrm{w}}\left(\mathrm{T}_{\mathrm{c}, \text { out }}-\mathrm{T}_{\mathrm{c}, \text { in }}\right)$

$=\mathrm{U}_{0} \mathrm{~A}_{0}(\mathrm{LMTD})$

Here, we need to find mass flow rate of cooling water and the temperature at the exit of the heat exchanger.

Heat transfer area $=\mathrm{n} \times \pi \times \mathrm{d}_{\mathrm{c}} \times \mathrm{l}$

Where $\mathrm{dc}=$ mean diameter of tubes.

Diameter of the outer surface (D) $=24 \mathrm{~mm}$

Diameter of the inner surface $(\mathrm{d})=20 \mathrm{~mm}$ $\mathrm{dc}=\frac{D+d}{2}=\frac{24+20}{2}=22 \mathrm{~mm}$

$$
\text { Heat transfer area } \begin{aligned}
\left(\mathrm{A}_{0}\right) & =\mathrm{n} \times \pi \times \mathrm{d}_{\mathrm{c}} \times 1 \\
& =9000 \times 3.14 \times 22 \times 10^{-3} \times 17 \\
& =10569.5 \mathrm{~m} 2
\end{aligned}
$$

Overall heat transfer co efficient $=1915.4 \mathrm{~W} / \mathrm{m} 2{ }^{\circ} \mathrm{C}$

From Energy balance:

$3 / 4 \times \mathrm{m}_{\text {steam }} \times\left(\mathrm{xh}_{\mathrm{fg}}\right)=\mathrm{U}_{0} \mathrm{~A}_{0}(\mathrm{LMTD})$

$3 / 4 \times 80.14 \times 0.8512 \times 2343.652 \times 1000=1915.4 \times 10569.5 \times$

LMTD

$\mathrm{LMTD}=5.92^{\circ} \mathrm{C}$

$\mathrm{LMTD}=\frac{(\text { 51.77-Tc,out })-(51.77-38.16)}{\ln \frac{51.77-\mathrm{Tc}, \text { out }}{51.77-38.16}}$

$\therefore \mathrm{Tc}$, out $=47^{\circ} \mathrm{C}$ (From trail \&error approach)

Cooling water exit temperature $\left(\mathrm{T}_{\mathrm{c}, \text { out }}\right)=47^{\circ} \mathrm{C}$

Efficiency of condenser $=\frac{\mathrm{Tc}, \text { out }-\mathrm{Tc} \text {,in }}{\text { Tsat } @ \mathrm{cp}-\mathrm{Tc} \text {,in }}$
$=\frac{47-38.16}{66.42-38.16}$

Efficiency of condenser $=31.2 \%$ 


\section{CONCLUSION}

The steam condenser is one among the foremost important element in whole power station installation. Their proper design and operation makes a big contribution to the efficiency of electricity production. The main function of a condenser is to only eliminate the latent heat of vaporization so that the temperature of condensate equals to the saturation temperature of steam corresponding to the condenser pressure. The increase in vacuum decreases the condenser pressure and lowers the saturation temperature which is a prime requisite for the high performance of the hybrid steam condenser. The corrugated nature of water carrying tubes will increase the efficiency of heat transfer because of increased surface area. The surface are of corrugated tubes is $10 \%$ higher than the surface area of existing condenser. It has been observed theoretically that a rise in $42 \%$ of thermal efficiency of condenser from existing surface condenser design to hybrid steam condenser with corrugated tubes design. This improvement will affect huge cost savings in power production industry. The only precautions need to be taken care are, cooling water should be of a good quality - free from impurities and suction pump capacity should be more to get jet condensate from the mixing chamber and to discharge it to hot-well.

\section{REFERENCES}

[1] Roy, R. P., M. Ratisher, and V. K. Gokhale. "A computational model of a power plant steam condenser." J. Energy Resour. Technol. 123.1 (2001): 81-91

[2] Park, Yong Gap, et al. "A study on the optimal arrangement of tube bundle for the performance enhancement of a steam turbine surface condenser." Applied Thermal Engineering 166 (2020): 114681.

[3] Tarrad, Ali Hussain, and H. M. Kamal. "A Model for Prediction of Surface Condenser Performance in Thermal Power Plants." Journal of Eng. And Development 8.3 (2004).

[4] Abadi, SMA Noori Rahim, M. Mehrabi, and Josua P. Meyer. "Numerical study of steam condensation inside a long, inclined, smooth tube at different saturation temperatures." International Journal of Heat and Mass Transfer 126 (2018): 15-25.

[5] Dehbi, A., F. Janasz, and B. Bell. "Prediction of steam condensation in the presence of noncondensable gases using a CFD-based approach." Nuclear Engineering and Design 258 (2013): 199-210.
[6] Prabu, S. Senthur, et al. "Experimental Study on Performance of Steam Condenser in 600MW Singareni Thermal Power Plant." International Journal of Mechanical Engineering and Technology 9.3 (2018).

[7] Jasim, Hisham Hassan. "A Numerical and Experimental Study of Steam Condenser Working with Modified Rankine Cycle." Engineering and Technology Journal 31.1 Part (A) Engineering (2013): 156-171.

[8] Majeed, Laith Mouayyad, and Ali Hussain Tarrad. "The Application of a Step by Step Technique for the Performance Prediction Of Thermal Power Plant Surface Condensers." Journal of Engineering 16.1 (2010): 4748-4770.

[9] A. Howell et al. (2005), Condenser Technology Conference, (San Diego, U.S.A.), Electric Power Researc+h Institute, Palo Alto, CA, U.S.A, 1010322

[10] Chisholm, D., T. F. Provan, and D. Mitchell. "Digital Computation Methods for Evaluating Heat Flux in Condensers." Journal of Mechanical Engineering Science 7.2 (1965): 177-184.

[11] B. J. Davidson (1987), Thermal design of condensers for large turbines, Aerothermodynamics of Low Pressure Steam Turbine and Condensers, Ch. 8, M. J. Moore and C. H. Sieverding, Eds., Hemisphere Publishing Corp.

[12] E. Hajidavalloo and H. Eghtedari (2010), Performance improvement of air-cooled refrigeration system by using evaporatively cooled air condenser. Int J Refrig 33:982-988.

[13] K. J. Bell (1983), Trends in design and application of condensers in the process industries, Condensers: Theory and Practice, The Institution of Chemical Engineers Symposium Series No. 75

[14] Q. W. Wang et al. (2008), CFD simulation on a thermal power plant with air-cooled heat exchanger system in north China. Int $J$ Comput Aided Eng Softw 25(4):342-365.

[15] R. E. Putman and R. Walker, Proc., International conference on Power Station Maintenance 2000(Oxford, United Kingdom), 2000.The Institution of Mechanical Engineers, London, United Kingdom, 161.

[16] Kapooria, R. K., S. Kumar, and K. S. Kasana. "An analysis of a thermal power plant working on a Rankine cycle: A theoretical investigation." Journal of Energy in Southern Africa 19.1 (2008): 77-83.

[17] Kapooria, Raj Kumar, S. Kumar, and K. S. Kasana. "Technological investigations and efficiency analysis of a steam heat exchange condenser: conceptual design of a hybrid steam condenser." Journal of energy in southern Africa 19.3 (2008): 35 45 . 